УДК 616-002.5-021.3-053.2-09

DOI: 10.26435/UC.VOI1(30).160

Р.Ф. Махмутов, Е.В. Золото, В.Г. Воробьева, М.Ю. Бусурин, А.И. Бобровицкая, Л.А. Захарова

ГОО ВПО «Донецкий национальный медицинский университет имени М. Горького», Донецк

\title{
КЛИНИКО-ГЕМАТОЛОГИЧЕСКИЕ ОСОБЕННОСТИ ПРИ ЧАСТЫХ И РЕЦИДИВИРУЮЩИХ ЗАБОЛЕВАНИЯХ У ДЕТЕЙ
}

Всемирная организация здравоохранения (ВО3) уделяет особое внимание проблеме улучшения состояния здоровья детей и подростков. Актуальной проблемой современной медицины и здравоохранения остается поиск улучшения здоровья детей и подростков. Укрепление здоровья детей и подростков, роль различных факторов его оптимизации определяют одно из ведущих направлений развития социальной политики государства и являются важнейшей стратегической задачей современного детского здравоохранения, так как от уровня здоровья данной группы населения зависит здоровье нации в целом, увеличение продолжительности активной жизни и творческое долголетие [1-3].

Согласно данным ВО3 ежегодно около 1,2 млн. смертей детей и подростков в возрасте от 10 лет до 19 лет в год происходят из-за обстоятельств, которые можно предотвратить. К частым причинам смерти, которой можно было бы избежать, относят дорожно-транспортные происшествия, заболевания дыхательной и пищеварительной системы, жестокое обращение в семье, осложнения подростковой беременности и самоубийства. В целом, наибольшее количество подобных смертей приходится на бедные районы Юго-Восточной Азии и Африки.

В структуре общей заболеваемости детей патология органов дыхания занимает первое место и составляет 2/3. При этом, количество заболеваний возрастает преимущественно за счет острых и рецидивирующих болезней верхних дыхательных путей. Дети, подверженные частым и рецидивирующим респираторным заболеваниям любой этиологии, - основной контингент по формированию хронических очагов инфекции. Среди часто болеющих детей неблагоприятный преморбидный фон встречается в 1,5-2,5 раза чаще, уровень общей заболеваемости в 3,5 раза выше, ЛОР-патология выявляется в 82-90\% случаев по сравнению с детьми, болеющими эпизодически. Этому способствует по- вышенное микробное обсеменение верхних дыхательных путей, а также снижение естественной резистентности организма и иммунологической реактивности организма [4-6]

\section{ЦЕЛЬРАБОТЫ}

Изучить клинико-гематологические особенности у детей с частыми и рецидивирующими заболеваниями на основе изучения индексов расширенной гемограммы.

\section{МАТЕРИАЛ И МЕТОДЫ}

Ретроспективно изучены клиникопатогенетические особенности у 267 часто и длительно болеющих детей с хронической патологией верхних дыхательных путей. Детей в возрасте от 1 года до 7 лет было 140 (52,4\%), 7-14 лет - 85 (31,8\%), подростков - 42 (15,8\%). Для оценки состояния здоровья детей, а также характера рецидивов хронических очагов инфекции, определялись ряд индексов путем изучения расширенной гемограммы: лейкоцитарный индекс интоксикации (ЛИИ) по формуле КальфКалифа Я.Я. (1975); модифицированный лейкоцитарный индекс интоксикации - ЛИИм; реактивный ответ нейтрофилов (POH); индекс сдвига лейкоцитов крови (ИСЛК); индекс соотношения лейкоцитов и СОЭ (ИСЛСОЭ); лимфоцитарногранулоцитарный индекс (ЛГИ).

Полученные в процессе исследования клинические и лабораторные показатели были обработаны методом математической статистики с помощью компьютерного пакета обработки данных Statistica v. 6 для работы в системе Windows (Statsoft, USA). Определяли основные статистические характеристики: среднее арифметическое (М), средняя ошибка (m), показатель достоверности различий (p).

(c) Р.Ф. Махмутов, Е.В. Золото, В.Г. Воробьева, М.Ю. Бусурин, А.И. Бобровицкая, Л.А. Захарова, 2019

(c) Университетская Клиника, 2019 


\section{РЕЗУЛЬТАТЫ ИОБСУЖДЕНИЕ}

Проведенная оценка состояния здоровья у 267 часто и длительно болеющих детей позволила установить, что в периоде ремиссии дети имели различные заболевания верхних дыхательных путей: хронический тонзиллит 110 (41,2\%) случаев; хронический аденоидит 83(31,0\%); рецидивирующий бронхит 42 (15,7\%); хронический фарингит 31 (11,6\%); хронический ринит $1(0,5 \%)$.

Эпидемиологические исследования позволили выявить, что в течение одного года каждый ребенок имел заболевания верхних дыхательных путей 6,0ะ2,1 раза. Дети дошкольного и школьного возраста переносили заболевания чаще в 4,8 и в 2,9 раза по сравнению с подростками. Причем заболеваемость была выше у детей раннего возраста (25,5\%), дошкольников $(29,3 \%)$ и младших школьников (28,0\%) по сравнению с детьми старшего школьного возраста и подростками $(17,2 \%)$ - составила $82,8 \%$. Острые респираторные заболевания у 38,0\% детей встречались чаще по сравнению со сверстниками - на их долю приходилось 57,3\% всех случаев.

Старт первого эпизода острой респираторной вирусной инфекции на первом году жизни, особенно во втором полугодии, отмечался у часто болеющих детей в 72,0\% случаев. Максимальная кратность и длительность эпизодов ОРВИ и наличие вторичных очагов инфекции в виде аденоидных вегетаций наблюдалась преимущественно у детей дошкольного возраста $(55,4 \%)-$ начало посещения детского коллектива.

Рецидивирующие заболевания у всех детей обусловлены основными причинами: а) экзогенными факторами - низким уровнем материально-бытовых условий жизни $(44,2 \%)$; временным фактором, в частности, осеннезимний период $(73,7 \%)$; началом посещения детьми дошкольных учреждений $(33,4 \%)$; ятрогенией - нерациональное использование лекарственных препаратов (14,9\%); б) эндогенными факторами: перинатальная отягощенность регистрировалась в 67,4\% случаев; фоновые состояния в раннем периоде жизни в виде гипотрофии $(15,7 \%)$, рахита $(29,2 \%)$, раннего искусственного вскармливания $(52,4 \%)$; наличие проявлений атопического дерматита (41,2\%).

У часто болеющих детей регистрировалась микрополиадения (100\%) и астенический синдром (56,4\%). У 69,6\% детей с хроническим аденоидитом причины гипертрофии носоглоточной миндалины были разнообразными: неблагоприятные бытовые условия и недостаточное питание в 14,2\% случаях; аллергические процессы с персистирующими круглогодичными или аллергическими ринитами - 11,9\%; наличие в анамнезе лимфатико-гипопластического диатеза - 8,2\%; атопического дерматита - 16,1\%. Аденоиды у 46,4\% детей были истинно гипертрофированными (II-III степень) и у $25,8 \%$ - находились в состоянии хронического воспаления, сопровождающегося характерной воспалительной отечностью. Аденоидные вегетации сочетались с гипертрофией небных миндалин в 8,6\% случаев, аденоидит с хроническим синуситом - в 5,2\%.

Клиническими проявлениями аденоидита являлись: постоянно выраженное затруднение носового дыхания, гнусавость голоса, неприятный запах изо рта, челюстно-лицевые аномалии. Гемограмма у детей характеризовалась наличием минимальных признаков воспаления только у $11,9 \%$.

Хронический тонзиллит, как правило, регистрировался у 39,7\% детей школьного возраста и характеризовался в периоде ремиссии наличием субфебрильной температуры, неприятных ощущений в горле и казеозных масс в лакунах миндалин, болезненной пальпации подчелюстных лимфатических узлов. При осмотре ротоглотки небные миндалины гипертрофированные (I-II степень) с рубцовым изменением и уплотнены. При этом отмечалась гиперемия слизистой передних дужек миндалин. Гемограмма характеризовалась лейкоцитозом (10,3 1,3 Г/л), нейтрофильным сдвигом $(62,4 \pm 3,7 \%)$, моноцитопенией $(5,7 \pm 1,4)$, ускорением СОЭ $(18,3 \pm 1,7$ мм/час).

У часто болеющих детей с аденоидными вегетациями (11,2\%), хроническим тонзиллитом (28,5\%) при изучении микробиологического пейзажа ротоглотки выявлена патогенная флора: стафилококк - в 20,3\% случаев, стрептококк - в 18,7\%, пневмококк - в 0,7\% и грибы рода Candida - в 8,7\%. Формированию хронического фарингита у 6,0\% (34) детей способствовали: тонзиллит, гнойные воспаления придаточных пазух носа, ринит. Клиническая картина хронического фарингита характеризовалась ощущением инородного тела в горле, умеренными болями при глотании, нередко сухим кашлем, быстрым изменением голоса. При фарингоскопии отмечались: утолщение и разлитая гиперемия слизистой оболочки глотки с наличием вязкого слизистого или слизисто-гнойного секрета, отечность и утолщение язычка и мягкого неба.

Хронический ринит у детей (28), проживающих в г. Константиновке, развивался в результате длительного воздействия неблагоприятных факторов окружающей среды (повышенная запыленность и загазованность атмосферного воздуха по данным СЭС 2013-2014 гг.), наличия хронического воспалительного процесса в придаточных пазухах носа (5) и аденоидов (7). Кли- 
ническими проявлениями заболевания были постоянные выделения и заложенность носа, головная боль, снижение обоняния. При риноскопии цвет раковин бледно-розовый, с синюшным оттенком (6).

Рецидивирующий бронхит у 7,9\% (45) детей, как правило, развивался после перенесенной ОРВИ (27) или после обострения хронической инфекции (тонзиллита, аденоидита, гайморита) - у 18. Частота обострений бронхита у детей дошкольного возраста составляла $6,2 \pm 1,3$ раза в году, у школьников $-4,7 \pm 1,5$. Неполная ремиссия рецидивирующего бронхита (12 детей) сопровождалась кратковременным повышением температуры тела $(37,5 \pm 1,2 \circ \mathrm{o})$, выраженной головной болью и катаральными явлениями на фоне мало нарушенного общего состояния, сухим и болезненным кашлем, иногда приступообразного характера, который затем становился влажным с выделением небольшого количества слизи, в отдельных случаях мокроты.

При аускультации легких непостоянно определялись изменчивые по локализации разнокалиберные влажные и сухие хрипы, преимущественно на вдохе. В периоде обострения у 8 детей гемограмма характеризовалась легкой степени гипохромной анемией $(105,7 \pm 2,3$ г/л), незначительным лейкоцитозом (10,6 $\pm 1,4$ Г/л), ускорением СОЭ $(16,0 \pm 3,2$ мм/ч). На рентгенограмме легких наблюдались изменения в виде сетчатости и усиления прикорневого бронхососудистого рисунка.
При изучении индексов (ЛИИ, ЛИИм, РОН, ИСЛК, ИЛСОЭ, ЛГИ) на основании расширенного клинического анализа крови у всех часто болеющих детей с хроническими очагами инфекции верхних дыхательных путей, выявлено повышение на 18,7\% (ЛИИм), 52,9\% (РОН), 17,5\% (ИСЛК), 9,4\% (ИЛСОЭ) на фоне снижения на 13,3\% (ЛГИ) по сравнению с детьми, которые болели эпизодически, что подтверждает наличие аутоиммунного характера интоксикации, воспалительного процесса бактериального генеза в стадии компенсации и нарушение иммунологической реактивности организма у часто болеющих детей.

\section{В Ы В 0 д Ы}

1.Дети раннего, дошкольного и младшего школьного возраста болели приблизительно одинаково и составили $82,8 \%$, то есть в 4,9 раза чаще болели по сравнению с детьми старшего школьного возраста и подростками (17,2\%), что, вероятно, связано с началом посещения детских коллективов и несовершенством системы естественной резистентности организма.

2. Часто болеющие дети с хронической патологией верхних дыхательных путей имели, преимущественно, хронический тонзиллит и аденоидит $(81,1 \%)$ с проявлениями воспалительного процесса бактериального генеза в стадии компенсации, интоксикацию аутоиммунного характера и требуют реабилитации.

\section{Р.Ф. Махмутов, Е.В. Золото, В.Г. Воробъева, М.Ю. Бусурин, А.И. Бобровицкая, Л.А. Захарова}

ГОО ВПО «Донецкий национальный медицинский университет имени М. Горького», Донецк

\section{КЛИНИКО-ГЕМАТОЛОГИЧЕСКИЕ ОСОБЕННОСТИ ПРИ ЧАСТЫХ И РЕЦИДИВИРУЮЩИХ ЗАБОЛЕВАНИЯХ У ДЕТЕЙ}

Изучены некоторые клинико-гематологические особенности у 267 часто и длительно болеющих детей в возрасте от 1 года до 15 лет включительно.

Установлено, что дети раннего, дошкольного и младшего школьного возраста болели приблизительно одинаково и составили $82,8 \%$. Часто болеющие дети с хронической патологией верхних дыхатель- ных путей имели, преимущественно, хронический тонзиллит и аденоидит $(81,1 \%)$ с проявлениями воспалительного процесса бактериального генеза и требуют реабилитации.

Ключевые слова: дети, клинико-гематологические особенности, частые и рецидивирующие заболевания. 


\section{R.F. Makhmutov, E.V. Zoloto, V.G. Vorobyova, M.Yu. Busurin, A.I. Bobrovitskaya, L.A. Zakharova}

SEI HPE «M. Gorky Donetsk National Medical University», Donetsk

\section{CLINICAL AND HEMATOLOGICAL PECULIARITIES OF CHILDREN WITH FREQUENT AND RECURRENT DISEASES}

Some clinical and hematological peculiarities of 567 frequent and chronically ailing children from 1 year to 15 years old have been studied.

It was established, that preschool children and children of early and primary school age were ill approximately the same and made up $82,8 \%$.

Frequent and chronically ailing children with chronic

\section{ЛИТЕРАТУРА}

1. Полунина Н.В., Черкасов С.Н. Особенности состояния здоровья детей Российской Федерации и пути его улучшения. Приоритетные направления развития здравоохранения Дальнего востока и Байкальского региона: проблемы и перспективы сб. науч. трудов. Якутск; 2013: 203-207.

2. Полунина Н.В. Состояние здоровья детей в современной России и пути его улучшения. Вестник Росздравнадзора. 2013; 5; 17-24.

3. Заплатников А.Л., Харит С.М., Петров В.А. Индукторы интерферонов. Противовирусные иммуно- модулирующие эффекты в клинике детских инфекций. Поликлиника. 2010; 5; 25-27.

4. Костинов М.П., Лукачев И.В., Афиногенова В.П. Иммунотерапия: механизм действия и клиническое применение иммунокорригирующих препаратов. Лечащий врач. 2010; 4; 9-13.

5. Сапожников В.Г. Избранные главы детских болезней: монография. Тула: Полиграфинвест; 2015. 298.

6. Сапожников В.Г. Избранные главы детских болезней: монография. Тула: Полиграфинвест; 2016; 292. pathology of upper respiratory tract had predominantly chronic tonsillitis and adenoiditis $(81,1 \%)$ with manifestations of inflammatory process of bacterial genesis and require rehabilitations.

Key words: children, clinical and hematological peculiarities, frequent and recurrent diseases.

\section{REFERENCES}

1. Polunina N.V., Cherkasov S.N. Osobennosti sostoyaniya zdorov'ya detei Rossiiskoi Federatsii i puti ego uluchsheniya. Prioritetnye napravleniya razvitiya zdravookhraneniya Dal'nego vostoka i Baikal'skogo regiona: problemy i perspektivy sb. nauch. trudov. Yakutsk; 2013: 203-207 (in Russian).

2. Polunina N.V. Sostoyanie zdorov'ya detei v sovremennoi Rossii i puti ego uluchsheniya. Vestnik Roszdravnadzora. 2013; 5; 17-24 (in Russian).

3. Zaplatnikov A.L., Kharit S.M., Petrov V.A. Induktory interferonov. Protivovirusnye immuno- moduliruyushchie effekty v klinike detskikh infektsii. Poliklinika. 2010; 5; 2527 (in Russian).

4. Kostinov M.P., Lukachev I.V., Afinogenova V.P. Immunoterapiya: mekhanizm deistviya i klinicheskoe primenenie immunokorrigiruyushchikh preparatov. Lechashchii vrach. 2010; 4; 9-13 (in Russian).

5. Sapozhnikov V.G. Izbrannye glavy detskikh boleznei: monografiya. Tula: Poligrafinvest; 2015. 298 (in Russian).

6. Sapozhnikov V.G. Izbrannye glavy detskikh boleznei: monografiya. Tula: Poligrafinvest; 2016; 292 (in Russian). 